ПРОФЕСІЙНА ПІДГОТОВКА ПЕДАГОГІВ ДО МЕДІАОСВІТИ УЧНІВ У СПОЛУЧЕНИХ ШТАТАХ АМЕРИКИ: ПОГЛЯД АМЕРИКАНСЬКИХ УЧЕНИХ

\title{
PROFESSIONAL TRAINING OF TEACHERS FOR MEDIA EDUCATION OF STUDENTS IN THE USA: A VIEW OF AMERICAN SCIENTISTS
}

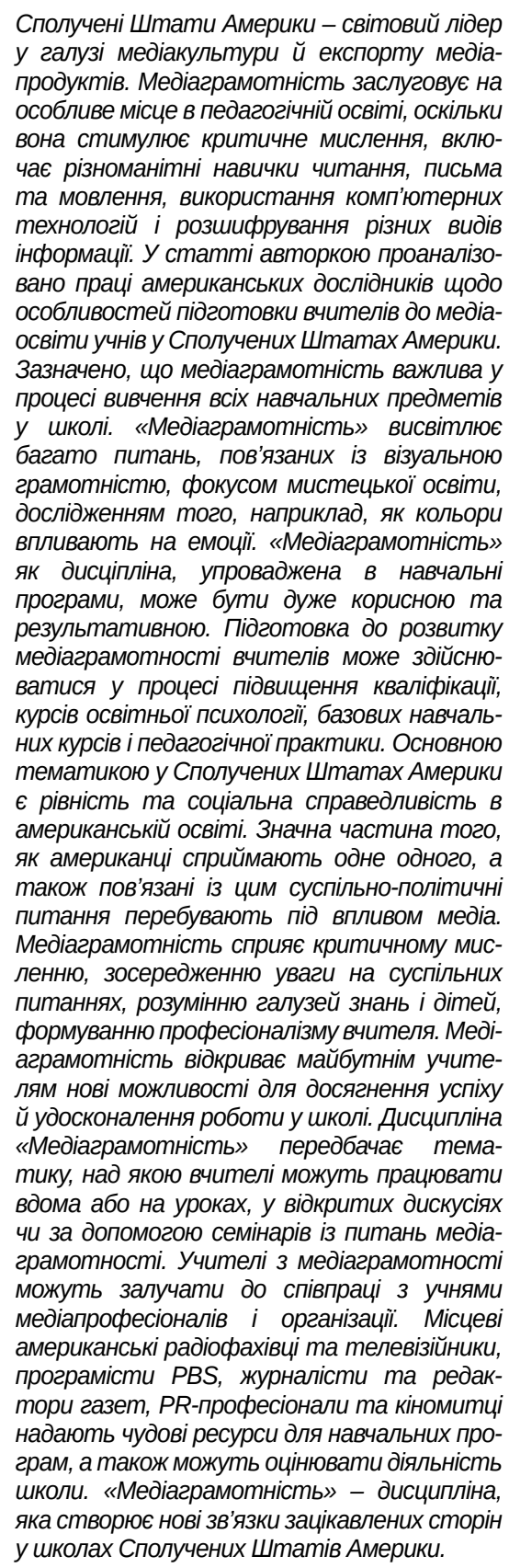

Сполучені Штати Америки - світовий лідер у галузі медіакультури й експорту медіапродуктів. Медіаграмотність заслуговує на особливе місце в педагогічній освіті, оскільки чає різноманітні навички читання, письма та мовлення, використання комп'ютерних технологій і розшиорування різних видів вано праці американських дослідників щидо особливостей підготовки вчителів до медіапроцесі вивчення всіх навчальних предметів у школі. «Медіаграмотність» висвітлює багато питань, пов'язаних із візуальною як кольори впливають на емоції. «Медіаграмотність» дисиіпліна, упроваджена в навчальні результативною. Підготовка до розвитку медіаграмотності вчителів може здійснюватися у процесі підвищення кваліфрікаціі, тематикою у Сполучених Штатах Америки $\epsilon$ рівність та соціальна справедливість в

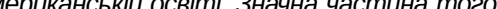
як американці сприймають одне одного, а також повязані із цим суспільно-політичні Медіаграмотність сприяє критичному мисленню, зосередженню уваги на суспільних питаннях, розумінню галузей знань і дітей, аграмотніс по

УДК 37.091.398

DOI https://doi.org/10.32843/2663-60852019-19-3-10

\footnotetext{
Приходькіна Н.О.,

канд. пед. наук,

доцент кафедри педагогіки, управління

та адміністрування

Університету менеджменту освіти

Національної академії педагогічних наук України,

докторант

Інституту педагогіки

Національної академії педагогічних наук України
}

Ключові слова: медіа, медіаграмотність, засоби масової інфрормації, критичне мислення, США, підготовка вчителів, навчальні дисципліни.

The USA is the world leader in the field of media culture and the export of media products in the world. Media literacy deserves a special place in teacher education, as it stimulates critical thinking, including a variety of reading, writing and speaking skills, the use of computer technology and the decoding of various types of information. In the article, the author analyzes the works of American researchers on the features of preparing teachers for media education of students in the United States of America. It is noted that media literacy is important in the process of studying all educational subjects at school. "Media literacy" overrides many issues related to visual literacy, the focus of art education, and the study of, for example, how colors affect emotions. "Media literacy", introduced into training programs, can be very useful and effective. Preparation for the development of media literacy of teachers can be carried out in the process of advanced training, educational psychology courses, basic training courses and teaching practice. The main theme in the United States is equality and social justice in American education. A significant part of how Americans perceive each other and related socio-political issues is influenced by the media. Media literacy contributes to critical thinking, focusing on social issues, understanding the branches of knowledge and children, and shaping teacher professionalism. Media literacy offers prospective teachers new opportunities to succeed and improve school performance. "Media literacy" offers topics that teachers can work at home or in media literacy classes, in open discussions or through seminars on media literacy. Teachers with media literacy can engage media professionals and organizations in collaboration with students. Local U.S. radio and television professionals, PBS programmers, journalists and newspaper editors, PR professionals and filmmakers provide excellent resources for curriculum and can evaluate school performance. "Media literacy" is a discipline that creates new stakeholder relationships in US schools.

Key words: media, media literacy, mass media, critical thinking, USA, teacher training, academic disciplines.
Постановка проблеми в загальному вигляді. Сполучені Штати Америки (далі - США) - світовий лідер у галузі медіакультури й експорту медіапродуктів. Засоби масової інфрормації (далі - ЗМІ) пронизують американську культуру наскрізно. Американці використовують відеоігри, радіо, CD-програвачі та смартфони; вони підписуються на журнали та газети, знімають відео, відвідують кінотеатри та проводять час в Інтернеті. 3МІ, особливо в минулому столітті, розширили уявлення про грамотність та способи навчання людей. Наприклад, К. Тайнер (1998 р.) зазначає, що «існує багато напрямів грамотності -у широкому розумінні, усному, друкованому й електронному форматі - $€$ кілька нерозривних процесів грамотності, які варто враховувати» [25, с. 38]. Усе більше вчених обговорюють багатошаровість грамотності й ідею, що традиційних читання і письма, що є основою грамотності, нині недостатньо для теперішніх американських учнів (див.: Moppic\&чуді, "The New 
Literacy: Moving Beyond the 3R's" («Нова грамотність: вихід за межі 3R's"), Майєрса, "Changing our minds: Negotiating English and Literacy” («Змінюючи розум: англійська мова та грамотність») [18; 19].

На думку Т. Бейлз, «хоча масовій культурі лише приблизно 150 років, справжню природу її впливу на суспільство загалом лише починають вивчати. Однак багато соціологів готові донести статус засобів масової інформації до рівня статусів сім'ї, церкви та школи як основних закладів, що впливають як на когнітивне навчання, так і на навчання соціальним та моральним цінностям» [2, с. 4].

Отже, освіта вчителів потребує медіаграмотності як важливого інструменту та найважливішого напряму в новому тисячолітті.

Аналіз останніх досліджень і публікацій. Особливості підготовки вчителів до медіаосвіти учнів у Сполучених Штатах Америки перебували в центрі наукових інтересів багатьох американських учених, зокрема: П. Аудерхайд, Д. Консідайн, М. Керрі-Таш, Г. Феррінгтона, Д. Хілі, В. Кілпатрика, Д. Робінсона, К. Тайнера й ін.

Мета статті - на основі аналізу досліджень американських учених розкрити особливості підготовки вчителів до медіаосвіти учнів у США.

Виклад основного матеріалу. Якщо проаналізувати праці американських дослідників медіаосвіти та медіаграмотності, то найкраще, на нашу думку, визначення медіаграмотності надала Патрісія Ауфдерхейд (P. Aufdcrheide), профресорка Школи комунікацій Університету Мінесоти, - це «здатність громадянина отримувати доступ, аналізувати (оцінювати) та надавати інформацію щодо конкретних результатів» [1, с. 5]. Розуміння та використання засобів спілкування - це здібності, які є основою життя в інформаційну епоху. Отже, медіаграмотність включає різноманітні навички читання, письма та мовлення, використання комп'ютера та розшифрування візуальних та навіть музичних презентацій інфрормації. Але медіаграмотність виходить за межі практичної інструкції. Дж. Робінсон (J. Robinson) пояснює: «Освіта 3 медіаграмотності навчає способів аналізу ретельно побудованих кодексів і конвенцій засобів масової інфрормації, що впливає на розуміння світу» [1]. Зрештою, засоби масової інфрормації впливають на те, як ми розмовляємо, що купуємо, за кого голосуємо, як ми сприймаємо інших і чому ми поводимось так, як поводимося. Е. Томан (E. Thoman) підсумовує: медіаграмотність - це «здатність створювати особистісну значущість із вербальних та візуальних символів, які ми щодня сприймаємо через телебачення, радіо, комп'ютери, газети та журнали, і, звичайно, рекламу. Це здатність обирати, здатність кинути виклик і запит, здатність бути свідомим щодо того, що відбувається навколо нас, а не бути пасивними і вразливими» [24, с. 50].
Оскільки батьки, педагоги, розробники медіа стурбовані впливом засобів масової інформації на американську молодь, суспільством була визнана важливість критичного мислення щодо цих засобів масової інформації, щоб стати свідомими, як радить Е. Томан. Подібно до того, як традиційна грамотність надає людям економічні, політичні та культурні можливості, так і медіаграмотність може надавати більше можливостей американським громадянам. Медіаграмотність - це не відмова від телебачення чи електронної пошти. Це сукупність навичок і поглядів, знань та розумінь. Медіаграмотність дозволяє формулювати питання, оскаржувати припущення, робити вибір, критикувати й оцінювати ЗМІ.

Навіщо впроваджувати медіаграмотність y педагогічну освіту США? Медіаграмотність заслуговує на особливе місце в педагогічній освіті, оскільки вона стимулює критичне мислення в епоху, коли молодь і вчителі інтенсивно використовують медіа; вона пропонує нові «способи залучення учнів до навчання; і це фрормує зв'язки між учнями, між школою й особистим життям, між учителями й іншими складовими частинами суспільного життя. Щоб зрозуміти американську культуру, а також культуру інших країн, зокрема, яким чином навчаються діти, що відбувається в усіх предметних галузях, для чого потрібна освіта, вчителі потребують опанування медіаграмотності. Педагоги також повині вміти моделювати медіаграмотність для своїх учнів.

Хоча програми підготовки вчителів у США нині включають освітні технології, медіаграмотність, що ґрунтується на критичному мисленні, ще недостатньо поширена. Наприклад, К. Тайнер (К. Tyner) стверджує: «Існує велика потреба в підготовці вчителів до викладання медіаграмотності» [26, с. 175]. Окрім того, майбутнім американським учителям потрібні знання щодо того, як створювати вебсторінки чи як обрати відповідні фрільми, як оцінювати навчальне програмне забезпечення, хто є власником більшості медіа, як насильство на телебаченні впливає на дітей тощо. ЗМІ та технології повинні бути інструментами, учителі повинні ставити запитання й ухвалювати політичні рішення.

США $є$ одним із лідерів з упровадження медіаосвіти, проте $є$ ще багато питань, як широких, так і вузьких, що потребують вирішення. Наприклад: Чи провокують цифрові регульовані зображення небезпечний цинізм? Чи могла б інформація знизити рівень сприйняття дітьми інших людей? Як комп'ютерні монітори впливають на зір дітей? Проаналізована нами інформація в таких виданнях, як Media Matters, Educational Leadership та The New York Times, підтверджує велику увагу до розвитку медіаграмотності у США, зокрема в таких штатах, як Міннесота і Техас, які у своїх освітніх стандартах зазначають медіаграмотність. Однак 
також зазначається «необхідність більш формального професійного розвитку педагогів та розробки навчальної програми 3 питань медіаграмотності в педагогічних коледжах» [24], також медіаграмотність може бути інтегрована в усі навчальні програми для педагогів.

Яким чином медіаграмотність пронизує педагогічну освіту? Предметно орієнтовані дисципліни $€$ закономірними осередками для впровадження медіаграмотності. Комунікація, мова, суспільство та всі людські чинники впливають на засоби масової інформації. Медіаграмотність як предмет і метод у словесності є основною частиною національних Стандартів 3 англійської мови (1996р.), що включають здатність читати і розуміти «широкий спектр друкованих текстів та рукописів». Розуміння та використання всіх фрорм спілкування $€$ основою мовного мистецтва. Медіаграмотність може привертати увагу учнів до методів пропаганди, відображення стереотипів у літературі друкованих текстах та рукописах - сприяти розвитку таких навичок, як читання, письмо. Майбутні вчителі у процесі вивчення таких дисциплін можуть знайти корисні ідеї для уроків, наприклад, запропоновані М. Керрі-Таш (М. Curry-Tush). На думку дослідниці, «медіа як інструктивний інструмент надає певні переваги, надає вчителям можливість відзначати виступи учнів, одночасно підштовхуючи їх до наукового успіху» [6, с. 46]. Порівняння літературних романів, практика вдалих методів дослідження означає більше, ніж просто завантаження інорормації з інтернету. Аналіз символів на телебаченні та дослідження багатьох питань медіаграмотності, від прав інтелектуальної власності до цензури, є потужними інструментами для вчителя англійської мови. Крім того, учні можуть продемонструвати своє розуміння різних предметів за допомогою різних медіа, наприклад, знявши відеозапис вистави або створивши вебсайт для перегляду книг. Медіаграмотність також може здійснюватися на різних рівнях, вона є суттєво важливою фрормою різнопланової грамотності в напрямі вивчення мови.

Медіаграмотність важлива у процесі вивчення дисципліни «Суспільствознавство». ЗМІ мають величезний вплив на американське суспільство, зокрема, політичне, економічне та культурне. Учителі суспільствознавства можуть навчати медіаграмотності для фрормування громадянської позиції, готуючи учнів до активної участі в демократії та протидії зростаючому політичному цинізму, що послаблює державу. Г. Хамот (G. Hamot), Д. Шивелі (J. Shiveley) та П. ВанФоссен (P. VanFossen) припускають, що медіа в суспільствознавстві дозволяють майбутнім учителям «розкривати приховані припущення, розрізняти релевантну та нерелевантну інфрормацію, розпізнавати фрейки, відокремлювати фракт від думки і, зрештою, визначати стійкість інфрормаційного середовища. Практикуючи медіаграмотність із учнями, педагоги можуть залучати їх докритичного діалогу стосовно медіа $<\ldots>$ > [13].

Вчителі суспільствознавства можуть ознайомити молодь із різними джерелами новин, включаючи «альтернативні» джерела; навчити учнів порівнювати новини 3 різних джерел; деконструювати або аналізувати розповіді в телевізійних новинах, наприклад, 60Minutes; навчити дієвих методів дослідження, включаючи інтерв'ювання; а також обговорювати вплив медіа, використовуючи такі джерела, як MassMedia (1994 р.) із серії «Протилежні погляди «Грінхейвен Прес»» (Сан-Дієго, Каліфрорнія). MassMedia містить уривки із творів письменників, які досліджували різні теми щодо 3МІ: від упередженості до регулювання. Учні також можуть створювати власні місцеві програми новин для кабельних каналів. Інші важливі теми суспільного вивчення медіаграмотності включають матеріалізм та надмірне споживання в капіталістичних суспільствах, вивчення історії за допомогою фрільмівітелебачення, економіки задопомогою реклами. Дослідження медіа -це не просто цікавий спосіб уникнути звичайних аудиторних лекцій. Критичне мислення щодо медіа повинно бути основним питанням курсів із суспільствознавства у США.

Медіаграмотність також може бути інтегрована до іншихдисциплін, але дещо меншою мірою. Посилюється роль медіаграмотності в медичній освіті. Наприклад, телебачення, що має значний вплив на фрізичну підготовку дітей, провокує насильство та безкарну сексуальну поведінку, прищеплює молоді шкідливі звички (паління, уживання алкоголю тощо). Учні можуть вивчати способи змалювання зображень і опосередкування природного світу. На думку Г. Феррінгтона (G. Ferrington) i Л. Андерсон-Інмана (L. Anderson-Inman), «наукові фрільми використовують різні спеціалізовані технології, включаючи анімацію, покадрову і швидкісну кінозйомку. Вивчення цих методів не тільки розширює розуміння учнями наукових принципів, але й забезпечує практичні навички деконструкції засобів масової інформації, які потім можуть бути перенесені на інший формальний та неформальний досвід навчання» [9, с. 668]. Медіаграмотність перекриває багато питань, пов'язаних із візуальною грамотністю, фокусом мистецької освіти, дослідженням того, наприклад, як кольори впливають на емоції. Медіаграмотність, впроваджена в навчальні програми, може бути дуже корисною та результативною.

Курси дитячої та підліткової психології в освіті педагогів повинні включати медіаграмотність, оскільки дослідники мають усвідомлювати вплив медіа на розвиток дитини. Наприклад, американська дослідниця Д. Хілі у праці "Failure to Connect" («Відсутність зв'язку») вивчає вплив викорис- 
тання комп'ютерів на розвиток мозку дитини. Вона попереджає: «Більшу частину нової техніки або неправильно застосовують, або невикористовують їі, коли вона надходить до школи; мало того, що машини простоюють через відсутність технічної підтримки чи підготовки вчителів, але погана реалізація програмного забезпечення перетворює час навчання на тривіальну гру <...> I нам не вистачає як ґрунтовних досліджень, так і вказівок щодо використання нових технологій у більшості конструктивних шляхів для дітей <...> [14, с. 22]. Дослідження приводять Д. Хілі до висновку, що комп'ютери можуть шкодити психічному зростанню дітей віком до семи років, і тоді їх слід використовувати обережно. Час перед екраном комп'ютера може позбавити маленьких дітей природних ігрових можливостей та взаємодії 3 дорослими, що необхідно для розвитку мови, інших напрямів розвитку. У книзі "Endangered Mind" («Вимираючий розум») Д. Хілі досліджує вплив інших медіа, зокрема телебачення, на здібності мислення дітей. Майбутні вчителі повинні знати такі деталі й ознайомитись із цим дослідженням [15].

Медіаграмотність єо сновним питанням, що потребує вирішення, у психології підлітків. Американський учений В. Штрасбургер (V. Strasburger) [22] досліджував наслідки насильства в медіа, а також зв'язки між медіа та вживанням наркотиків, харчуванням підлітків та підлітковою сексуальністю. Курс психології підлітків може бути справді значущим для майбутніх учителів. Співбесіда і/ або проведення обстеження підлітків із метою виявлення їхніх телевізійних звичок, захоплення інтернетними журналами (домашні, спеціалізовані журнали) або їхньої реакції на MTV дасть майбутнім учителям можливість краще зрозуміти сучасних підлітків. Навіть більше, майбутні вчителі в закладах середньої освіти можуть читати й обговорювати такі дослідження, як праця американської дослідниці П. Герш “А Tribe Apart” («Плем'я нарізно»). П. Герш (Р. Hersch) пов'язує медіа 3 іншими чинниками, які відчужують сьогоднішню молодь. Вона зауважує: «Технології та медіа створюють світ без меж. Для підлітків доступний великий вибір способу життя, водночас коли батьки й оточення не забезпечують збалансованого почуття безпеки <...>. Найбільш приголомшливою для підлітків сьогодні $€$ їхня самотність <...> більш ізольована, ніж самотність інших поколінь» [16, с. 19]. В епоху, коли діти зростають на інфрормації з телебачення та відеомагнітофонів, мобільних телеоронів і персональних комп'ютерів, медіаграмотність $є$ ключовою ланкою для розуміння й управління психологічним, когнітивним і афективним розвитком американської молоді.

В інших курсах підготовки вчителів - у теоретичному аспекті освіти, практичному досвіді та курсах - медіаграмотність також актуальна.
Наприклад, у різних базових курсах суспільних дисциплін або у вступі до навчальних курсів основною тематикою $€$ рівність та соціальна справедливість в американській освіті. Значна частина того, як американці сприймають один одного, а також пов'язані із цим суспільно-політичні питання перебувають під впливом медіа, якщо не визначаються ними. Х. Жиру (H. Giroux) у дослідженні "Channel Sutfing" («Канал Sutfing: Расизм, засоби масової інформації та знищення молоді сьогодні») стверджує, що медіа стимулюють антидемократичні настрої, особливо в самовизначенні підлітків: «Демонізовані чи тривіалізовані молоді люди зображуються в голлівудських фрільмах як соціальна загроза, що сорормувалась після антиінтелектуальної, неприродної театральності таких зірок, як Джим Керрі та Кріс Фарлі. Якщо молодь не демонізують, то показують у світлі комедії або як споживачів. У деяких випадках ця кодифікація молоді зачіпає етичні межі, наприклад, у рекламі виставляють на загал хтиві образи молоді у гламурних журналах, нав'язуючи зловживання наркотиками, щоб створити естетику, яку називають «героїновим шиком»» [12, с. 2].

Корисним, на думку американських дослідників, є впровадження медіаграмотністі до практичних курсів підготовки вчителів, зокрема в теми про роль учителів у закладах освіти та методи навчання. Наприклад, Г. Дегаетано (G. DeGaetano) та К. Бандер (K. Bander) [8] радять у процесі практичних курсів для майбутніх учителівзакладів середньої освіти використовувати для аналізу «навчальні фрільми», як-от "Dangerous Minds" («Небезпечні думки»), "Stand and Deliver" («Встань і дістань»), "Mr. Holland's Opus" («Опус містера Холланда»). Під час обговорення в аудиторії оцінюється, наскільки реалістичні ці зображення, які повідомлення пропонуються у фрільмах про школу та дітей, особливо з урахуванням реального шкільного досвіду вчителів. Постають важливі питання: чи хороший учитель той, хто бореться наодинці, як учитель з багатьох голлівудських історій? Якими постають перед нами директори шкіл? Якою мірою вчителі мають бути причетними до особистого життя своїх учнів? Чи в усіх школах є місце насильству? Майбутнім учителям під час розроблення власних освітніх фрілософій потрібно знати такі історії шкільного навчання, про які йдеться в медіа.

Нині американський учитель бере на себе багато ролей. Окрім інструктора, фрасилітатора, тренера, наставника, а іноді і радника, учитель також повинен бути готовим до співпраці з батьками, управлінцями та громадськістю, а також адвокатами, коли йдеться про заміну школи. Медіаграмотність пропонує майбутнім учителям нові можливості для досягнення успіху й удосконалення роботи у школі. Медіаграмотність пропонує тематику, над якою вчителі можуть пра- 
цювати вдома або на уроках 3 медіаграмотності, у відкритих дискусіях чи за допомогою семінарів із питань медіаграмотності. Отже, медіаграмотність $€$ додатковою темою для будь-яких занять, наприклад, навчального семінару 3 акцентуванням уваги на пропаганді. Багато американських батьків стурбовані поширенням медіа, тому використовують позитивні пропозиції 3МІ, запропоновані в "The Family New Media Guide"(«Сімейний путівник по ЗМІ») У. Кілпатрика (W. Kilpatrick), Г. Вулф (G. Wolfe) і C. Вулф (S. Wolfe) [17]. Учителі можуть ділитися іншими ресурсами, серед яких "Screen Smarts: A family Guide to Media Literacy" («Екранні думки: сімейний путівник із медійної грамотності») Г. Дегаетано та К. Бандер [17], "Plugged In Parent: What you should know about Kids and Computers" («Залучення батьків: що треба знати про дітей та комп'ютери») C. Беннета (S. Bennett) [3]. Ці книги доступні та практичні, пропонують учителям корисні ідеї для занять. Досвідчені вчителі можуть також обмінюватися інформацією про такі організації, як телебачення Family Choice TV (група з більш ніж 300000 осіб пропонує батькам ресурсні матеріали, семінари та громадські заходи). Учителі з медіаграмотності можуть залучати до співпраці з учнями медіапрофресіоналів і організації. Місцеві американські радіофахівці та телевізійники, програмісти PBS, журналісти та редактори газет, PR-професіонали та кіномитці надають чудові ресурси для навчальних програм, а також можуть оцінювати діяльність школи. Медіаграмотність $€$ дисципліною, яка створює нові зв'язки зацікавлених сторін у школах США.

Які переваги медіаграмотності для вчителів та їхніх учнів? Г. Гербнер (G. Gerbner) [11] стверджує, що нині медіа показують американцям історії американської культури, історії, які колись розповідали сім'ї, церкви, школи та суспільство. Найважливіші матеріали навчальних програм для вчителів повинні підготувати майбутніх викладачів до таких розповідей - власних історій. Якщо майбутні вчителі готові взяти контроль над своїм профресійним життям, впливати на політику у сорері освіти, щоб робити те, що буде найкращим для їхніх учнів і школи, вони $є$ ефективними у спілкуванні в реальному часі - складна, ситуативна і часто неоднозначна історія, що триває в американській школі. Те, що медіа створили неправдиві або хибні історії про американську освіту, підтверджує таке дослідження, як "Manufactured Crisis" («Виробнича криза»), у якому Д. Берлінер (D. Berliner) і Б. Біддл (B. Biddle) [4] деталізують популярний міфр про занепад та недоліки стандартів. На думку авторів, політики й інші посадовці регулярно змінюють матеріали шкіл відповідно до своїх програм. Те, що слід підтримувати, більшість нових виклада- чів упроваджують у навчання самостійно, завдяки своєму альтруїзму та комптентностям.

Медіаграмотність, яка дозволяє американським учителям викладати свої ідеї, покращує їхню професійну ефективність. Учитель може практикувати проведення презентацій технологічних потреб на шкільних нарадах і РТА. У процесі викладання теоретичних і практичних курсів майбутні вчителі навчаються публікувати свої розповіді в місцевих газетах, на телебаченні та радіостанції, ілюструючи, як навчаються учні, як функціонують школи, як громадськість може підтримати школи. Учителі можуть стати агентами змін, а не лише суб'єктами рефрорм інших людей.

Кінцевими бенефіціарами медіаграмотності в освіті педагогів $є$ діти. Вчителі, які $є$ критичними мислителями та профремійними комунікаторами, кваліфріковані та вдумливі щодо використання технологій у процесі викладання різних дисциплін, які розуміють власну культуру та культуру інших - це вчителі, які можуть допомогти своїм учням досягти тих же цілей у власному житті. Д. Консідайн (D. Considine) виділяє такі переваги медіаграмотності, важливі длямайбутніх викладачів:

1. Медіаграмотність $€$ міждисциплінарною галуззю, яку легко інтегрувати у ключові елементи існуючого навчальногоплану.

2. Медіаграмотність - це проблемно орієнтований напрям, насичений рефрлективним навчанням і критичним мисленням.

3. Медіаграмотність включаєпрактичне навчання та відповідає дослідженню стилів навчання.

4. Медіаграмотність добре спрацьовує в колективах і групах, сприяючи спільному навчанню.

5. Медіаграмотність успішно діє, коли справа стосується залучення учнів із метою покращення показника «відсіву».

6. Медіаграмотність сумісна зі SCANS (Комісія з питань здобуття необхідних навичок) та сприяє працевлаштуванню.

7. Медіаграмотність пов'язує навчальну програму для класу 3 навчальною програмою для широкого кола споживачів освітніх послуг [5, с. 41].

Висновки. Отже, медіаграмотність - це напрям, завдяки якому розширена грамотність може впроваджуватись в освітній процес у школах Америки на всіх рівнях. Вона є стимулом і зв'язком для курсів підвищення кваліфікації педагогів, курсів освітньої психології, базових навчальних курсів та педагогічної практики. Медіаграмотність сприяє критичному мисленню, зосередженню уваги на суспільних питаннях, розумінню галузей знань та дітей, формуванню професіоналізму вчителя. Це дає можливість учителям заявляти про себе. Як стверджує Дж. Девіс (J. Davies), «медіаграмотність містить те, що зробить учителів найкращими» [7, с. 170]. 


\section{БІБЛІОГРАФІЧНИЙ СПИСОК:}

1. Aufderheide P. Media literacy: A report of the National Leadership Conference on Media Literacy. Washington, DC : The Aspen Institute, 1992. URL: https://files.eric.ed.gov/fulltext/ED365294.pdf.

2. Bales T. The dumbing of America: Education in the media age. 1989. URL: https://www.learntechlib.org/ p/146753/.

3. Bennett S. The plugged-in parent. New York : Crown Business ; 1st edition, 1998. 185 p.

4. Berliner D., Biddle B. The manufactured crisis. 1995. URL: https://pdfs.semanticscholar.org/b567/ e99716ce1e8db2e54c36be044fa3a0cd57ee.pdf.

5. Considine D. Are we there yet? An update on the media literacy movement. Educational Technology. 1995. № 35 (4). P. 32-45.

6. Curry-Tash M. The politics of teleliteracy and advertising in the classroom. English Journal. 1998. № 87 (1). P. 43-48.

7. Davies J. Educating students in a media-saturated culture. Lancaster, PA : Technomic Publishing, 1996. $311 \mathrm{p}$.

8. DeGaetano G., Bander K. Screen smarts. Boston, MA : Houghton Miffin, 1996. 206 p.

9. Ferrington G., Anderson-Inman L. Madia literacy: Upront and on-line. Journal of Adolescent and Adult Literacy. 1996. № 39. P. 666-670.

10. Garrison A. Trends and Issues Statement. Media Matters. 2000. № 11 (4). P. 1-2.

11. Gerbner G. Forward: Invasion of the story sellers. Harvesting minds: How TV commercials control kids. Westport, CT : Praeger, 1996.

12. Giroux H. Channel surfing. New York : St. Martin's Griffin, 1997. URL: https://www.jstor.org/stable/ 23767591 ? read - now $=1 \&$ refreqid=excelsior $\%$ 3 A 15 cbd71e 6 ca3 2 efd 12 e 76292 fc $271872 \&$ seq=1\#page_scan_tab_contents.

13. Hamot G., Shiveley J., VanFossen P. Media literacy in social studies education: Relating meaning to practice. 1997. URL: https://www.medialit. org/reading-room/where-media-literacy-fits-worldeducation.

14. Healy J. Failure to connect. New York : Simon \& Schuster, 1998. 352 p.

15. Healy J. Endangered minds. New York : Touchstone Book, 1990. 382 p.

16. Hersch P. A tribe apart. New York : Fawcett Columbine, 1998. $416 \mathrm{p}$.

17. Kilparick W., Wolfe G. The family new media guide. New York : Touchstone, 1997. URL: http://booksuninterested.maweb.eu/4/7739012/1241411824/012The-Family-New-Media-Guide.pdf.

18. Morris P., Tchudi S. The new literacy: Moving beyond the 3 r's. Portland, ME : Cedar Island Publishers, 1996. $286 \mathrm{p}$.

19. Myers M. Changing our minds: Negotiating English and literacy. Urbana, IL : National Council of Teachers of English, 1996. 357 p.

20. Robinson J. Introduction to media literacy and media education bibliography. 1996. URL: https://files. eric.ed.gov/fulltext/ED403611.pdf.

21. Standarts for the English language arts. Urbana, IL : National Council of Teachers of English and International Reading Association. URL: http://www.ncte.org/ standards/ncte-ira.

22. Strasburger V. Adolescents and the media. Thousand Oaks, CA : Sage, 1995. URL: https://www.researchgate.net/publication/232600005 Adolescents_and_the_media_Medical_and_psychological impact _Developmental_clinical_psychölogy_and psychiatry_Vol_33.

23. Thoman E. Skills and strategies for media education. Educational Leadership. 1999. № 56 (5). P. 50-54.

24. Tyner K. Literacy in a digital world. Mahwah, NJ : Lawrence Erlbaum, 1998. 304 p. URL: https://www.taylorfrancis.com/books/9781410601971.

25. Tyner K. The tale of the elephant: Media education in the United States. New directions: Media education worldwide / C. Bazalgette, E. Bevort, J. Savion. London, UK : British Film Institute, 1992. P. 170-176. 